7. Садовникова Н.А., Шмойлова Р.А. Анализ временных рядов и прогнозирование: учебник для вузов. М.: Ун-т Синергия, 2016. - 151 с.

8. Бендерская Е.Н., Никитин К.В. Рекуррентная нейронная сеть как динамическая система и подходы к ее обучению // Научно-технические ведомости Санкт-Петербургского государственного политехнического университета. Информатика. Телекоммуникации. Управление. - 2013. № 4. - С. 29-40.

9. Рудой Г.И. Выбор функции активации при прогнозировании нейронными сетями // Машинное обучение и анализ данных. - 2011. - Т. 1, №1. - С. 16-39. - Текст электронный. - URL: http://jmlda.org/papers/doc/2011/JMLDA2011no1.pdf]. (Дата обращения 8.10.2020).

10. Джулли А., Пал С. Библиотека Keras - инструмент глубокого обучения / Под ред. Мовчан Д. А.; пер. А.А. Слинкин. - М.: ДМК Пресс, 2017. - 294 с.

\title{
ОБОСНОВАНИЕ НЕОБХОДИМОСТИ ВВЕДЕНИЯ ДОПОЛНИТЕЛЬНОГО ФАКТОРА ДЛЯ РАСЧЕТА КОЛИЧЕСТВА ВОЗДУХА, НЕОБХОДИМОГО ДЛЯ ПРОВЕТРИВАНИЯ НЕФТЯНЫХ ШАХТ
}

\author{
Д.Ю. Седнев, К.В. Симонова \\ Горный институт УрО РАН, г. Пермь
}

\begin{abstract}
Аннотация: Расчет количества воздуха для проветривания уклонных блоков нефтяных шахт должен производиться с учетом теплового фактора, позволяющего учесть тепловыделен ия и обеспечить соблюдение температурно-влажностного режима в буровых галереях. Тепловой фактор является определяющим фактором при расчете количества воздуха, необходимого для проветривания буровых галерей нефтяных шахт и рассчитывается на основе данных о площадях и температурах поверхностей горных выработок уклонных блоков, а также о тепловом потоке, выделяемом оборудованием. Учет теплового фактора при расчетах вентиляции необходим для поддержания микроклиматических параметров в подземных горных выработках в пределах, определяемых правилами промышленной безопасности.
\end{abstract}

Ключевые слова: нефтяная шахта, проветривание, уклонный блок, тепловой фактор, критерий предельного вентиляционного пути.

Нефтяные шахты Ярегского нефтетитанового месторождения (недропользователь ООО «ЛУКОЙЛ-Коми») являются специфическими горными предприятиями, в подземных горных выработках которых ведется добыча тяжелой высоковязкой нефти. Система разработки термошахтная, сбор нефти осуществляется в уклонных блоках. Уклонный блок представляет собой систему горных выработок (уклон, ходок, буровая галерея, насосные камеры, сбойки), включающую сетку добычных и парораспределительных скважин. Длина скважин, пробуренных из буровых галерей, в настоящее время составляет около $800 \mathrm{M}$.

Для сбора нефти в буровых галереях в настоящее время используется система сбора нефтесодержащей жидкости (НСЖ) открытого типа. НСЖ из добывающих скважин самотеком или под давлением пара поступает в водоотливные канавки и по ним стекает в водонефтяной зумпф уклонного блока, откуда откачивается насосами на центральную нефтеперекачивающую станцию либо на поверхность.

Система проветривания нефтяной шахты является одной из важнейших систем жизнеобеспечения, и требует постоянного контроля и оценки факторов, которые могут напрямую или косвенно оказывать влияние на эффективность ее работы. Основной задачей проветривания является создание в рабочих зонах условий труда, пригодных для профессиональной деятельности горнорабочих, а именно: обеспечение 
рабочей зоны требуемым количеством воздуха; снижение концентрации выделяющихся и образующихся в процессе горных и нефтедобычных работ ядовитых и горючих газов до допустимых пределов, а также удаление их из рабочей зоны; поддержание безопасных для персонала микроклиматических параметров шахтной атмосферы.

Основным действующим нормативным документом в части обеспечения микроклиматических параметров в нефтяных шахтах являются ФНИП «Правила промышленной безопасности при разработке нефтяных месторождений шахтных способом» [1]. Основные требования в части микроклимата, приведенные в [1]: насосная камера является постоянным рабочим местом с температурой воздуха не более $+26^{\circ} \mathrm{C}$, в буровой галерее допускается температура рудничной атмосферы до $+36^{\circ} \mathrm{C}$ включительно (при кратковременном пребывании персонала). В 2017 году сотрудниками ГИ УрО РАН в нефтяных шахтах №№ 1, 2, 3 были проведены воздушно-депрессионные и температурно-влажностные съемки, результаты которых показали наличие температур шахтного воздуха выше отметки $+36^{\circ} \mathrm{C}$ в местах с непостоянным пребыванием персонала и выше $+26^{\circ} \mathrm{C}$ в насосных камерах с постоянным пребыванием людей $[2,3,4]$. Стоит отметить, что рабочий температурный диапазон работы шахтного самоспасателя не превышает $+40^{\circ} \mathrm{C}$ (на ряде участков было зафиксировано превышение температуры $+40^{\circ} \mathrm{C}$, что недопустимо).

Общее количество обследованных буровых галерей и насосных камер уклонных блоков, в которых наблюдается нарушение микроклиматических параметров, на момент съемки равнялось 16, или 53\% от их общего количества. Остальные буровые галереи уклонных блоков находились или в стадии проходки, или на начальном этапе прогрева массива. На рис. 1 приведены термограммы буровой галереи уклонного блока нефтяной шахты № 3.

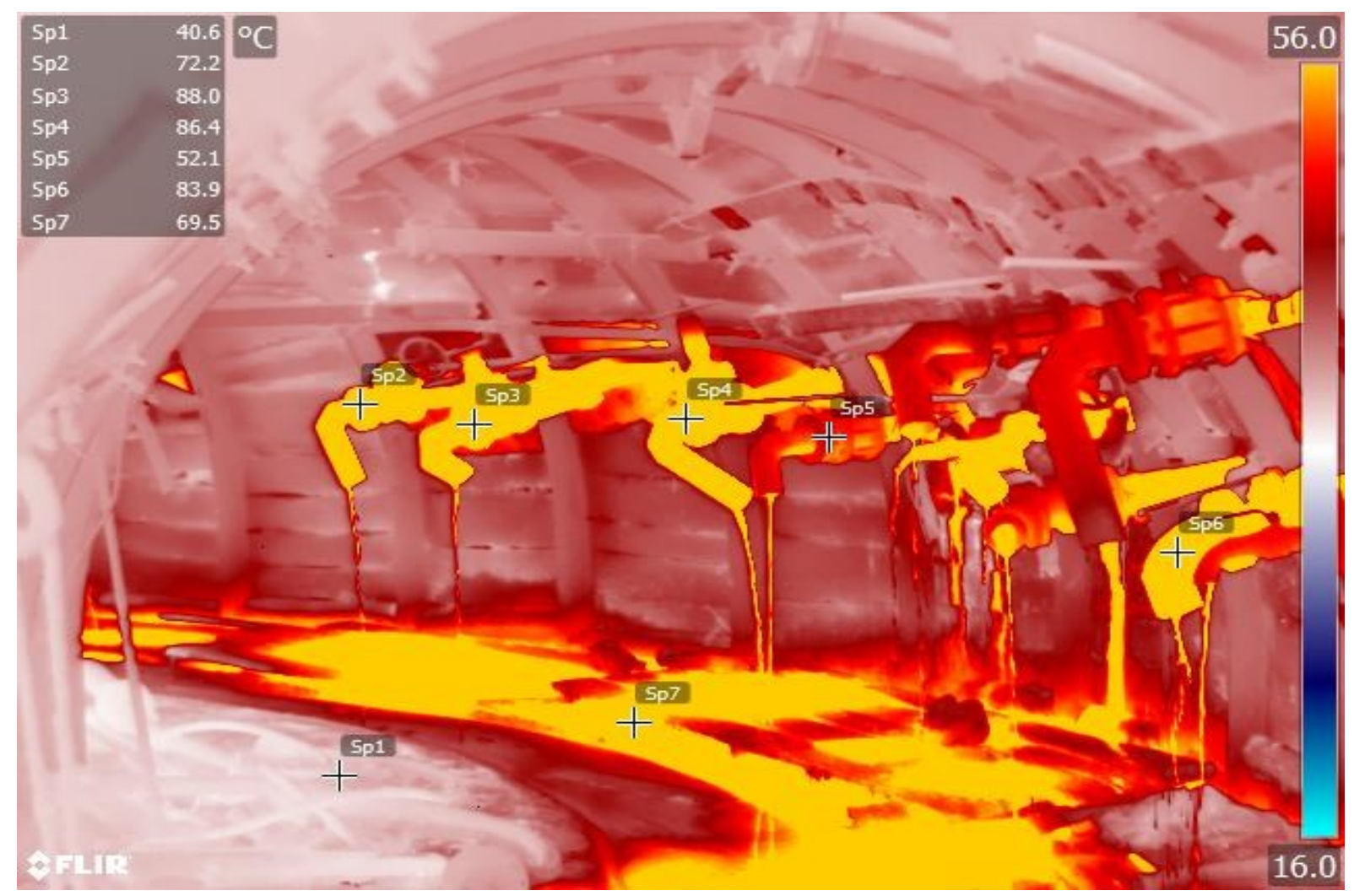

Рис. 1. Тепловизионная съемка в буровой галерее уклонного блока 4Т-4 
В уклонном блоке температура воздуха значительно превышает $+36^{\circ} \mathrm{C}$ за счет контакта с разогретыми стенками буровой галереи.

На температуру в уклонном блоке оказывают влияние следующие факторы:

1) тепловыделения от стенок, подошвы, кровли горных выработок и от канавки,

2) тепловыделения от паропровода (при его наличии),

3) длина горных выработок, находящихся в нефтяном пласте,

4) скорость движения воздуха, его температура и влажность,

5) площади сечений горных выработок.

Расчет количества воздуха для проветривания буровых галерей уклонных блоков производится по следующим факторам: минимальная скорость, тепловой фактор и газовыделения. Буровая галерея представляет собой источник тепла с равномерно распределенной тепловой нагрузкой. Основное требование при расчете по тепловому фактору - отсутствие превышения температуры, равной $+36^{\circ} \mathrm{C}$. Задачей при этом является определение такой скорости воздуха в заданных условиях 1) 5 ), при которой будет выполнено условие непревышения температуры $+36^{\circ} \mathrm{C}$ (либо другой, более низкой, определяемой предъявляемыми проектной документацией). Ранее действовавшие «Правила безопасности при разработке нефтяных месторождений шахтным способом», утвержденные Постановлением Госгортехнадзора СССР от 11.04.1986 N 8, предусматривали обеспечение соблюдения температурного режима путем задания минимальной скорости воздуха $(2 \mathrm{~m} / \mathrm{c}$ для выработок с температурой более $+26^{\circ} \mathrm{C}$ ) в зависимости от температуры в горных выработках согласно п. 3.8. При этом для буровых галерей максимальная скорость воздуха была ограничена $6 \mathrm{~m} / \mathrm{c}$.

Применение данного подхода показало свою несостоятельность, что подтверждено результатами съемок. В результате работ по подготовке проектной документации для нефтяных шахт была подготовлена инструкция по расчету количества воздуха, необходимого для проветривания нефтяных шахт, лишенная указанных недостатков и позволяющая учесть тепловой фактор при расчете количества воздуха, подаваемого в буровые галереи.

Согласно методике, сначала требуется задать результат расчета - максимальную температуру воздуха на выходе из буровой галереи (например, $\left.+36^{\circ} \mathrm{C}\right)$. Далее происходит построение эпюры температуры воздуха вдоль вентиляционного пути (выработок уклонного блока). Расчет значений температуры воздуха в точках эпюры выполняется итерационно, с учетом задаваемых входных характеристик 1) - 5), а также с учетом мероприятий по теплоизоляции стенок, кровли и почвы выработок.

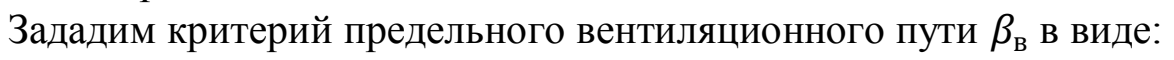

$$
\beta_{\mathrm{B}}=\frac{L_{\phi}}{L_{\mathrm{B}}}<1,
$$

где $L_{\phi}$ - фактическая протяженность горных выработок, в которых происходит нагрев воздуха, м, $L_{\text {в }}-$ путь, который должен пройти при указанных условиях воздух, чтобы достичь предельно допустимой температуры, м.

Пример эпюры температур приведен на рисунке 2 , где $T_{\max }, T_{\min }$ - ожидаемая температура в горной выработке с учетом стратификации температуры по высоте выработки.

Определение температуры в каждой точке вдоль оси горной выработки по ходу движения вентиляционной струи определяется с помощью математического моделирования в ANSYS либо аналитическим методом с помощью уравнений теплового баланса уклонных блоков (в данной статье не рассматриваются). 
При проектировании уклонного блока с термошахтным способом разработки выполнение критерия предельного вентиляционного пути является достаточным и необходимым условием для учета теплового фактора, а, следовательно, выбора скорости воздуха и поддержания оптимальной температуры в горных выработках.

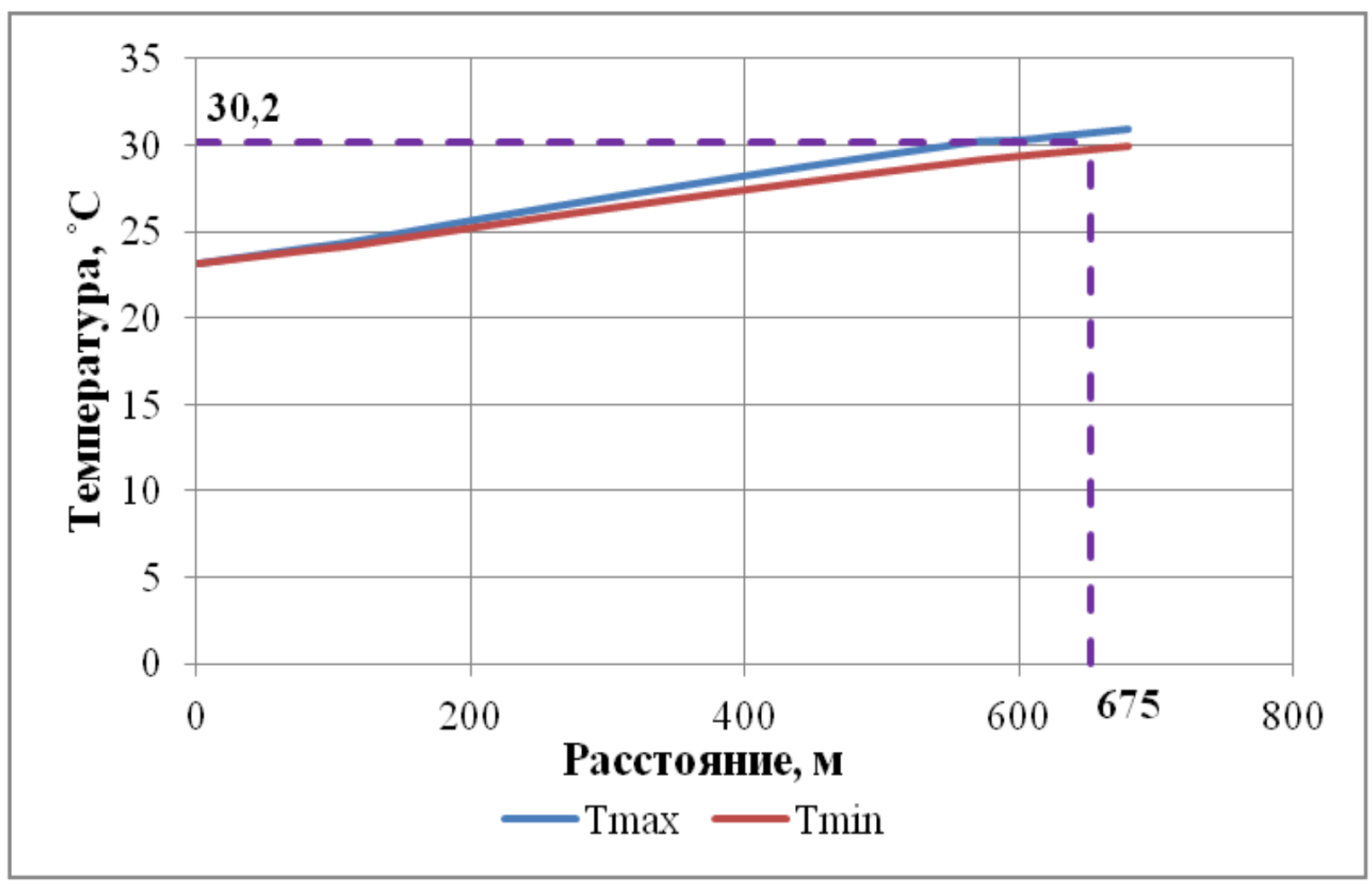

Рис. 2. Пример графика определения критерия вентиляционного пути

\section{БИБЛИОГРАФИЧЕСКИЙ СПИСОК}

1. Федеральные нормы и правила в области промышленной безопасности «Правила промышленной безопасности при разработке нефтяных месторождений шахтным способом»: утв. 28.11.2016, № 501. - Текст электронный // Консорциум КОДЕКС. Электронный фонд правовой и нормативнотехнической документации: офиц. сайт. - URL: http://docs.cntd.ru/document/420385052 (Дата обращения: 15.03.2020).

2. Определение основных источников тепловыделения в горных выработках нефтяных шахт № 1, 2, 3, с учетом результатов воздушно-депрессионных и температурно-влажностных съемок нефтяных шахт № 1, 2, 3. Разработка компьютерных моделей вентиляционных с етей нефтяных шахт № 1, 2, 3. Нефтяная шахта № 1: Отчет о НИР / ГИ УрО РАН. - Пермь, 2017. - 179 c.

3. Определение основных источников тепловыделения в горных выработках нефтяных шахт № 1, 2, 3, с учетом результатов воздушно-депрессионных и температурно-влажностных съемок нефтяных шахт № 1, 2, 3. Разработка компьютерных моделей вентиляционных с етей нефтяных шахт № 1, 2, 3. Нефтяная шахта № 2: Отчет о НИР / ГИ УрО РАН. - Пермь, 2017. - 117 c.

4. Определение основных источников тепловыделения в горных выработках нефтяных шахт № 1, 2, 3, с учетом результатов воздушно-депрессионных и температурно-влажностных съемок нефтяных шахт № 1, 2, 3. Разработка компьютерных моделей вентиляционных сетей нефтяных шахт № 1, 2, 3. Нефтяная шахта № 3: Отчет о НИР / ГИ УрО РАН. - Пермь, 2017. - 154 c. 